NBER WORKING PAPER SERIES

\title{
THE CAUSES AND CONSEQUENCES OF INCREASED FEMALE EDUCATION AND LABOR FORCE PARTICIPATION IN DEVELOPING COUNTRIES
}

\author{
Rachel Heath \\ Seema Jayachandran \\ Working Paper 22766 \\ http://www.nber.org/papers/w22766 \\ NATIONAL BUREAU OF ECONOMIC RESEARCH \\ 1050 Massachusetts Avenue \\ Cambridge, MA 02138 \\ October 2016, Revised August 2017
}

Prepared for inclusion in the Oxford Handbook on the Economics of Women, ed. Susan L. Averett, Laura M. Argys and Saul D. Hoffman. (New York: Oxford University Press. Forthcoming, 2018). We thank Alejandro Favela for excellent research assistance and Pinar Keskin and Rafael Santos for very helpful comments. The views expressed herein are those of the authors and do not necessarily reflect the views of the National Bureau of Economic Research.

NBER working papers are circulated for discussion and comment purposes. They have not been peer-reviewed or been subject to the review by the NBER Board of Directors that accompanies official NBER publications.

(C) 2016 by Rachel Heath and Seema Jayachandran. All rights reserved. Short sections of text, not to exceed two paragraphs, may be quoted without explicit permission provided that full credit, including $(\odot)$ notice, is given to the source. 
The Causes and Consequences of Increased Female Education and Labor Force Participation in Developing Countries

Rachel Heath and Seema Jayachandran

NBER Working Paper No. 22766

October 2016, Revised August 2017

JEL No. J16,O15

\section{ABSTRACT}

Two important recent trends in most developing countries have are the rise in female labor force participation and the closing of gender gaps in school enrollment. This article begins by exploring the causes of the increases in female education, which include greater job availability and policy interventions that have promoted girls' education. The article then explores the causes of increased female employment, which include a sectoral shift from "brawn-based" industries to services, as well as policies that have increased girls' education. The article also discusses the effects of these increases in female education and labor supply, particularly for the well-being of women.

Rachel Heath

Department of Economics University of Washington

Box 353330

Seattle, WA 98103

rmheath@uw.edu

Seema Jayachandran

Department of Economics

Northwestern University

2211 Campus Dr

Evanston, IL 60208

and NBER

seema@northwestern.edu 


\section{Introduction}

Two important recent trends in most developing countries are the rise in female labor force participation and the closing of gender gaps in school enrollment. In this article, we explore both the causes and the effects that they have had on the lives of women. A central theme that emerges is the relationship between the two phenomena: as increases in education have prompted more women to enter the labor force, improved labor market opportunities have also prompted increases in female education.

We begin by exploring the causes of the increases in female education. In addition to the role of greater job availability, we also discuss policy interventions that have promoted girls' education. Recent evidence indicates that providing cash or in-kind benefits to parents who keep their daughters in school, building schools or improving facilities, and developing programs to reduce general gender disparities can all lead to increases in girls' education.

We then turn to the causes of increased female employment. Against the backdrop of the wellknown theory that female labor supply is U-shaped in development (Boserup, 1970; Goldin, 1995; Mammen and Paxson, 2000), we provide evidence both that poor countries are moving along the U-shaped curve as they develop and that the curve has shifted over time. Low-income countries are on the downward-sloping portion of the empirically-estimated U-shaped curve, which would suggest that their female employment rate would be declining as their economies grow. However, we show that the U-shaped curve has been shifting upward in recent decades: female labor force participation has increased, conditional on a country's income. The net effect of movement along the curve and the shift in the curve is that even the poorest countries in the world have generally experienced rising female employment. Some of the employment growth has been generated by a sectoral shift from "brawn" to services, which is occurring earlier in the development trajectory than predicted by the U-shape. We also argue that policies that have increased girls' education have contributed to the upwards shift. Furthermore, we cite evidence that programs seeking to improve women's earning potential (such as microfinance or business skills training) or to reduce the burdens of home production (such as free child care) have had some success in increasing female labor supply. If these programs are adopted on a large-scale, they could contribute to a further shift upwards.

In the second half of the article, we document the effects of these increases in education and labor supply. In addition to increased labor supply, there is considerable evidence that female education delays fertility and leads to healthier children once a woman has them. There is some evidence, although it is less extensive, that women with more education marry later and on better terms, and are healthier themselves. 
We conclude by discussing the effects of increased labor supply on women. We present research that shows that job availability increases women's bargaining power, even if they do not work themselves. At the same time, holding constant job availability, working itself leads to even greater increases in women's bargaining power and children's health. While these outcomes both represent improvements in women's utility and are frequent policy goals, we also discuss evidence that there may also be concurrent increases in domestic violence or reductions in women's leisure time that make the net effect for women's welfare less clear.

\section{Determinants of female education and labor supply}

\section{2a. Determinants of increases in education}

There is a pronounced male bias in educational attainment at low levels of economic development, which is absent among richer societies. Figure 1 shows the relationship between gender gaps in education and development by plotting the female-to-male ratio in secondary school enrollment rates in countries around the world against GDP per capita. The ratio is below 1 in most poor countries - meaning that female enrollment is lower than male enrollment -- but in richer countries there is gender parity or, in fact, female enrollment exceeds male enrollment.

The pattern seen in the cross-section of countries is also seen over time in most poor countries as their economies grow: girls' education increases at a faster rate than boys', narrowing the gender gap. Figure 2 plots the trend in secondary school completion rate for females relative to males among low-income countries in Sub-Saharan Africa and Asia. While education levels for both genders have been rising over time (not depicted in the figure), the growth is more rapid for females as indicated by the increasing ratio female-to-male education ratio.

\section{Economic forces affecting female education}

There are several potential reasons for the rise in female education and, more specifically, the faster rise in female than male education. First, if the female employment rate is rising and education confers benefits in the labor market, then forward-looking families will invest more in girls' education over time. Should families in developing countries be anticipating a rising female employment rate? Female employment could increase with development for many reasons, as discussed in Jayachandran (2015) and briefly reviewed here. As economic activity shifts away from "brawn-based" work and toward "brain-based" work, such as in the services sector, female workers gain a comparative advantage (Pitt, Rosenzweig, and Hassan, 2012). Reductions in fertility, better control over the timing of fertility, and improvements in maternal health also increase women's time in the labor market (Jayachandran and Lleras-Muney, 2009; Miller, 2010). While there are also some potential channels through which female employment might instead decrease with development -- as discussed in the next section -- we also show 
that the positive channels have dominated negative channels in a majority of countries, so that female employment has indeed risen in most countries over the past 20 years.

There are also other channels besides female employment that could be driving the rise in girls' education that accompanies economic development. The opportunity cost of schooling might fall due to decreases in parents' fertility and in the time-intensity of home production: girls' time that they had spent caring for siblings or doing household chores is freed up, enabling them to stay in school longer.

These explanations do not rest on any societal favoritism toward boys. However, part of the gender gap in education may very well reflect favoritism. Thus, another potential explanation for the rising education of girls is that educating children has consumption value for parents, with girls' education more of a luxury good than boys' education; with rising family incomes, spending on girls begins to catch up to spending on boys. In addition, economic development might alter preferences and reduce gender-biased attitudes. Stated gender bias tends to be negatively correlated with economic development, although we do not have causal evidence that economic development systematically ameliorates gender-biased attitudes (Jayachandran, 2015).

Gender-focused policies affecting female education

In addition to the economic forces that accompany development leading to more female education, there are many policies directed at increasing female education that have been put in place in recent decades. One type of policy involves school infrastructure. Building more schools could be a girl-friendly policy if parents are more sensitive to travel distance when deciding to send girls to schools (Burde and Linden, 2013). Similarly, building toilets in schools might be more important for girls' enrollment than boys' (Adukia, forthcoming). Many developing countries have eliminated school fees for primary schools, and such a policy might especially help girls if parents were reluctant to invest money in their education.

Another type of policy to increase girls' education is conditional cash transfers (CCTs). Prominent programs such as Oportunidades in Mexico pay families a larger amount to keep their daughters in school than their sons, under the view that a larger amount is needed to induce them to educate a daughter than a son, and some CCTs only target girls (Schultz, 2004). An in-kind CCT in India gives bicycles to girls who remained in secondary school; such a policy both provides an incentive to remain in school and makes traveling to school faster and safer. This program increased female secondary school enrollment by $30 \%$ in the state of Bihar, and the authors attribute most of the effect to the reduced travel time and increased safety, rather than the cash-equivalent incentive effect (Muralidharan and Prakash, 2013). 
In other cases, policies aimed at improving female welfare, though not directly increasing female education, might have positive spillovers onto education. For example, there is evidence that the granting of land inheritance rights to women in India increased girls' schooling. This might have been due to either newly empowered mothers pushing for greater education of their daughters or a complementarity between land ownership and education, with an increase in perceived returns to education for girls in anticipation of their future inheritance (Deininger, Goyal, and Nagarajan, 2013; Roy, 2013). In addition, quotas that increased female representation in elected positions in India led to more education for girls, presumably by raising girls' own aspirations and their parents' aspirations for them (Beaman et al., 2012). Policies to ban or discourage early marriage of girls might also increase girls' schooling by decreasing the opportunity cost of schooling; Field and Ambrus (2008) present evidence from Bangladesh consistent with such a channel.

\section{2b. Determinants of increases in labor supply}

A well-known theory of female employment and development posits that there is a U-shaped relationship between female employment and economic development (Boserup, 1970; Goldin, 1995). At early stages of development, women do unpaid work on family farms and in family businesses. With development, economic activity migrates to factories and firms, and women tend to withdraw from the labor force. This could be due to both households being less economically dependent on two incomes and social stigma about women working in these outside jobs. Working outside the home is also harder to combine with caring for children than is home-based work, and child-care responsibilities typically lie with women. Then, with higher levels of development, female employment swings back up again. The increase in female employment is driven by a sectoral shift toward light manufacturing and services, among other factors. Women have a comparative advantage in mentally-intensive services (as compared to physically-intensive agriculture, for example), and service jobs might also be deemed more socially acceptable than other jobs.

Figure 3 plots the relationship between GDP and the female labor force participation rate across countries using the most current available data. In addition to the data point for each country, the figure plots the best-fit quadratic relation. While there is considerable dispersion across countries, the best-fit relationship is indeed a U-shape.

Under this U-shaped model of female employment and development, depending on whether a society is on the declining or rising part of the $U$, economic development could either increase or decrease female employment. "Developing" or "low-income" countries are, by and large, on the decreasing part of the curve. This means that among developing countries, the richer ones tend to have a lower female employment rate. (While the definition of developing countries is 
arbitrary, one grouping is the World Bank's low-income and lower-middle-income countries, which are those with GDP per capita below about \$4000 in 2014 U.S. constant dollars. One could also classify upper-middle-income countries as developing countries, in which case those with GDP per capita below about $\$ 12,500$ are included, which is roughly the bottom of the U).

While Figure 3 examines the relationship in a cross-section, Figure 4 looks for within-country evidence of the U-shape by plotting changes in women's employment between 1991 and 2011 versus the country's GDP in 1991. As countries grow (i.e., as their GDP increases), they should move rightward along the U. Thus, the U-shape theory predicts that female employment falls with GDP growth at low GDP, but increases with GDP growth at higher GDP; this prediction can be seen from the fact that the slope of a U-shape is negative on the left and then turns positive at the bottom of the U. In line with this prediction, Figure 4 shows that there is on average more positive growth in female employment among countries with higher GDP in 1991. However, there is no evidence for downward movement along the downward part of the $\mathrm{U}$ : the best-fit line never predicts negative growth in female employment. This mixed evidence suggests that the U-shape theory captures only part of the recent story with female employment: Yes, there are forces causing GDP growth to spur female employment more in richer countries, but there are also forces that have spurred female employment across the board in recent decades. Speculatively, the global push to increase female education might be one of these latter forces.

Indeed, there is evidence that in many countries, female labor force participation has been rising, conditional on income (World Bank, 2012). Figure 5 plots the best-fit U-shape over time, in 10 years intervals from 1991 to 2011. In panel A, which weights each country equally, the curve rises across each decade. In contrast, panel B, which weights each country by population, shows a rise between 1991 and 2001 but little progress after 2001; this pattern is consistent with female employment stagnating or declining in several populous countries, such as India (Klasen and Pieters, 2015).

To summarize, female employment levels have been rising in most developing countries, but how dramatic this trend has been depends on some important nuances of how one defines the question. First, it matters whether one examines trends unconditionally or conditional on income: while in poor countries, unconditional increases in female employment have been quite modest, this trend represents a large boost in female employment relative to a benchmark where these countries were predicted to have decreasing female employment as they moved along the downward part of the U. Second, it matters whether one weights by country or by person: female employment has been steadily rising if one weights each country equally, but has been stagnant recently when one weights each person equally. 


\section{Economic forces affecting female employment}

Increases in female education have been an important factor in the increased female labor force participation, particularly into relatively high-paying jobs. Economists have long noted a positive correlation between education and female labor force participation in most (although not all) developing countries (see Psacharopoulos and Tzannatos, 1989 for a summary), and recent natural experiments confirm that this relationship appears to be causal. Each year of education induced by the Zimbabwean reform studied by Grepin and Bharadwaj (2015) led to 3 percentage point increase in the probability that the woman works outside the home and lives in an urban area. Similarly, women induced to get more education by a 1997 law that increased compulsory schooling in Turkey from five to eight years were more likely to work outside the home and in jobs that provide social security benefits (Erten and Keskin, forthcoming). While the Ugandan reform studied by Keats (2014) did not change women's labor force participation on the extensive margin, it did increase the likelihood that women had migrated to the capital city and were working for cash. One interesting channel behind the shift to higher-paying jobs is increased mobility: education increases the probability of living in an urban area in Zimbabwe (Grepin and Bharadwaj, 2015) and in Kampala (Uganda's capital) (Keats 2014).

However, increased education does not universally translate into a higher probability of working. The increased education among women in Pakistan generated by the presence of a sex-specific school that Andrabi, Das, and Khwaja (2013) documented did not lead to greater labor force participation. A similar context of low female labor supply is the Zomba district in Malawi studied by Baird, McIntosh, and Ozler (2016), where only 6\% of women work outside the home. They show that many girls who had dropped out of school in rural Malawi were prompted to re-enter school by a cash transfer but were not more likely to be working two years after the transfers ended. These findings suggest that the presence of jobs that reward education is a necessary condition for education to result in increased labor force participation.

Intertwined with these increases in female education is the sectoral shift toward services and light manufacturing that generally accompanies development. Two examples of job growth in developing countries that has disproportionately increased female employment are back-office processing in India, as studied by Jensen (2012), and the garment industry in Bangladesh, as studied by Heath and Mobarak (2015).

Both back-office processing and growth in the garment industries are born of globalization and trade liberalization. Trade liberalization could affect gender gaps in employment and wages through many channels, so the net effect is theoretically ambiguous. One channel through which it could promote gender equality is by increasing competitive pressure on firms and, thus, driving out "taste-based discrimination" (Becker, 1957). There is some evidence of such an effect in the United States (Black and Brainerd, 2004). In addition, trade can induce 
technological change and lead to sectoral reallocation, which could either widen or narrow gender gaps. For example, if, with trade openness, a country has a comparative advantage in female-intensive industries, then trade could help women relative to men. The evidence in developing countries is mixed. AlAzzawi (2014) finds that, in Egypt, trade liberalization increased female employment only in initially uncompetitive industries, where industry competition is measured by the number of firms in the industry relative to the industry's total output. Meanwhile, Gaddis and Pieters (2016) find that trade liberalization in Brazil reduces men's and women's employment by the same proportional amount; because men had an initially higher employment rate, trade thus narrowed the percentage point gap in male-female employment, but not the male-female employment ratio. There is also evidence that trade openness can widen the gender wage gap in some settings (Menon and Van der Meulen Rodgers, 2009). Thus far, no systematic pattern has emerged regarding the impact of trade liberalization on female labor market outcomes.

\section{Gender-focused policies affecting female employment}

In addition, there are many policies and interventions aimed at encouraging female employment. Many of these have the twin goals of increasing household income, but also increasing the female share of income and therefore women's bargaining power in the household.

One prominent type of policy is microfinance, and especially microcredit, which gives small loans to poor business owners. While microfinance is not inherently a gendered policy, many microfinance organizations target female entrepreneurs. There have recently been several highquality randomized evaluations of microcredit. Most find some evidence of positive impacts on the opening of female-owned businesses or revenue generated in female-owned businesses, but the impacts tend to be quite modest in size (Angelucci, Karlan, and Zinman, 2015; Banerjee et al., 2015).

Another approach, often bundled with microfinance, is business skills training, which has been shown to improve women's business knowledge and success (De Mel, McKenzie, and Woodruff, 2014; Valdivia, 2015). Field, Jayachandran, and Pande (2010) argue that formal business training can be especially helpful in socially conservative communities where women are less free to casually interact with others and learn business tips informally. In addition, female entrepreneurs often have thinner business networks, so strengthening these peer interactions can also improve women's success (Field et al., 2016).

Another type of policy that has been deployed and studied extensively in developed countries (but is less widespread and studied in developing countries) is child care subsidies that free up mothers to re-enter the labor force. Most of the work in developing countries is in Latin 
America. Barros et al. (2011) find that access to free child-care services in Rio de Janeiro, Brazil, almost doubled the employment rate of mothers who were not working prior to receiving this benefit (from 9 to 17 percent). However, the increase in household income (from both this extensive margin and the intensive margin) was less than the monthly cost of service per child estimated. One would hypothesize that more generous maternity leave policies would also increase female employment, but such policies are rarely in place in developing countries and, in any case, many women work in the informal sector.

Many developing countries have gender-unequal laws and regulations that inhibit female employment such as restrictions on women working night shifts and barriers to women initiating legal proceedings. There is cross-country correlational evidence that lifting these discriminatory laws increases female employment (Gonzales et al., 2015); testing the causal impact of these laws on female employment would be a valuable area for further research.

\section{Consequences of increased female education and labor supply}

\section{3a. Consequences of increased female education}

The increases in education documented in Figure 2 have had wide-ranging consequences on women and their children. We first examine the relationship between women's education and fertility, children's health, and children's education. We then turn to the some limited evidence that women's education affects their own health and well-being.

One of the strongest empirical relationships is between education and early fertility: there is considerable evidence from a wide variety of settings that plausibly exogenous increases in women's education delay fertility. The INPRES school-building program in Indonesia (Breierova and Duflo, 2004), the Universal Primary Education program in Nigeria (Osili and Long, 2008), the elimination of primary schools fees in Uganda (Keats, 2014), and a school subsidy in Kenya (Duflo, Dupas, and Kremer, 2015) all increased education and lowered rates of teen pregnancy. While the variation in these studies is driven by primary education, Ozier (2015) also finds large decreases in teen pregnancy among women just above the test score cutoff for secondary school in Kenya.

The extent to which delays in fertility translate into lower lifetime fertility is more limited. In the Breierova and Duflo (2004) Indonesian sample, the effects of education on a woman's fertility had disappeared by age 25. By contrast, Osili and Long (2008) find that an additional year of schooling induced by the UPE program in Nigeria leads to 0.26 fewer births to a woman by age 25. The long-run evidence comes from Lavy and Zablotsky (2011), who study the effects of the 1963 revocation of a military government that relaxed constraints on schooling for Arab women in Israel. The reform lead to an average of 1.0 additional years of education for girls age 4 to 8 at 
the time of the reform and a corresponding 0.68 fewer children over their lives. Thus, it did not appear that education merely postponed fertility in their case.

Several potential mechanisms underlie the relationship between education and fertility. Broadly, education can change women's desired number of children (through exposure to more "liberal" ideals or through an increased opportunity cost of time spent out of the labor force), or allow them to better achieve their desired fertility in environments where women typically end up with more children than they report wanting. While it typically is difficult to cleanly identify one particular channel, there is suggestive evidence that both of these channels are relevant. More educated women report lower desired fertility (Martin 1995, Bongaarts 2010), and the relationship appears causal when examining exogenous variation in women's education in Uganda (Keats, 2014), Sierra Leone (Cannonier and Mocan, 2014), and Arab communities of Israel (Lavy and Zablotsky, 2011). Lavy and Zablotsky argue that the fact that their environment has very low female labor force participation suggests that decreases in desired fertility are not entirely driven by the increased opportunity cost of time spent not working.

Other studies find that better-educated women can come closer to their desired fertility. If women on average desire fewer children than men (Rasul, 2008; Ashraf, Field, and Lee, 2014; Doepke and Kindermann, 2016), then increases in bargaining power due to increased education will lower fertility. Indeed, in the Indonesian context studied by Breierova and Duflo where the woman's own education no longer had an effect on fertility by age 25 , increases in her education relative to her husband did still decrease fertility, suggesting a role for household bargaining. Or even if parents agree on the desired number of children, education still appears to increase the effectiveness of contraception methods. Rosenzweig and Schultz (1989) argue that more educated women in the United States are more effective at using complex contraceptive methods, such as the rhythm method, and the relationship between education and contraceptive effectiveness (as measured by the probability of becoming pregnant while using contraception) has persisted in more recent data (Bongaarts 2010).Once these moreeducated women have children, their children are also healthier. Early papers point out that the positive association between women's education and children's health generally statistically survives controls for husband characteristics and household socioeconomic status (Schultz, 1980; Thomas, Strauss, and Henriques, 1990), but not necessarily controls for community level factors (Desai and Alva, 1998) or family background (Wolfe and Behrman, 1987). One possible theory uniting these disparate findings is that the relationship between women's education and children's health depends on the availability of public health infrastructure (Rosenzweig and Schultz, 1982a; Wolfe and Behrman, 1982; Barrera, 1990).

Subsequent studies have isolated exogenous variation in education to confirm that on average a causal relationship exists between mother's education and reductions in child mortality. The 
relationship appears at many levels of education: primary school in Indonesia (Breierova and Duflo, 2004), junior high schools in Taiwan (Chou et al., 2010), and secondary schools in Zimbabwe (Grépin and Bharadwaj, 2015). Using a different identification strategy to separate intergenerational ability transmission from causal effects of education, Chen and Li (2009) document a relationship between the adoptive mother's education and children's health in China, which persists after controlling for the income of the adoptive family. They find roughly constant marginal effects of education, providing further evidence that increases in mother's education at all levels improves children's health.

Several potential mechanisms underlie these health improvements. Glewwe (1999) points out that educated women in Morocco know more about health, and Thomas, Strauss, and Henriques (1990) further show that in Brazil this correlation can be entirely explained by access to information, such as newspapers and television. Agüero and Bharadwaj (2014) use a 1980 reform that relaxed constraints on black Zimbabweans' access to secondary school to argue that the relationship is causal: education increases a woman's knowledge about how HIV is transmitted. The relationship between mother's education and the use of health inputs is more mixed. Grépin and Bharadwaj (2015) find no evidence that the tendency for mother's education to reduce infant mortality in Zimbabwe is driven by a greater use of preventative health care services. Keats (2014), by contrast, finds that more educated women in Uganda are more likely to immunize their children and finds improvements in child nutrition status but not reductions in child mortality. Güneş (2015) also finds that Turkish women induced to get more education by the 1997 compulsory schooling law increased their use of preventative care and smoked less while pregnant, which led to improved infant health.

There is some, although not considerable, evidence that mother's education improves children's educational outcomes. De Walque (2009) examines the relationship between adoptive parents' and adopted children's schooling in Rwanda. While acknowledging the possibility of selection, de Walque finds that adoptive mothers' education is strongly related to their children's schooling, more so than the biological mother's. Tsai et al. (2011) use the same Taiwanese reform as Chou et al. (2011) to show that exogenous increases in either mother's or father's schooling increased by 10 percent the probability that their child attended a top- 6 college. Behrman et al. (1999) and Andrabi et al. (2012) find that the key human capital investment increased by mother's education is not necessarily her children's years of education but rather the amount and quality of teaching she does at home. Andrabi et al. (2012) instrument mother's education in Pakistan with the availability of a girls' school in her hometown, arguing that the fact that the presence of a girls' school does not affect a mother's education if it was built after she had passed primary school age. They find that children of mothers with some education 
spend 72 more minutes per day in educational activities at home than those whose mothers have no education and as a result have higher tests scores.

The evidence on the relationship between women's education and their own health is also more limited. Bhalhotra and Cochrane (2013) show that exogenous increases in education decrease maternal mortality in Nigeria and Zimbabwe but not Kenya. De Neve et al. (2015) find that exogenous increases in secondary schooling decrease HIV risk in Botswana, and they find particularly large effects for women: an additional year of schooling reduces the cumulative risk of HIV by 11.6 percentage points. Cannonier and Mocan (2014) further show that education increases the probability that a woman has been tested for HIV.

Delayed marriage is another potential effect of female education. There is some evidence pointing to such an effect, although this phenomenon does not appear to be universal. Breierova and Duflo (2004) find that an additional year of education in Indonesia delays marriage by an average of 0.38 years. Duflo, Dupas, and Kremer (2015) also find that schooling delays marriage. By contrast, Keats (2014), Erten and Keskin (forthcoming), and Lavy and Zablotzky (2011) find no effect of education on marriage timing in Uganda, and among Arab women in Israel, respectively. The fact that the relationship between education and fertility is more widespread than the relationship between education and marriage timing is unsurprising, given that the latter hinges on marriage market responses, such as the extent to which potential husbands are also treated by the education reform (which would depend on age gaps between spouses and whether boys were affected by a particular education reform). Relatedly, the evidence on whether women entering the marriage market with exogenously more education marry more educated husbands is also mixed: Keats (2014) and Erten and Keskin (2016) find no effects on husband's education in Uganda and Turkey, respectively, while Lavy and Zablotzky (2011) do find evidence of increases in husband's education among their Israeli Arab sample.

Education can also change a woman's status within her household. Thomas (1990) points out that women's education displays a stronger correlation with daughters' health than sons', consistent with a relationship between women's education and bargaining power and mothers favoring daughters more or disfavoring them less than fathers do. Other studies, however, find a limited role for education in increasing a woman's bargaining power, as proxied by selfreported participation in household decisions (Andrabi, Das, and Khwaja, 2012; Keats, 2014). Erten and Keskin (2015) show that women induced to get more education by the Turkish reform face greater incidence of psychological violence or financial control, but the same rates of physical and sexual violence, as women with less education. Given that these women were also more likely to work outside the home, Erten and Keskin interpret these results in light of an instrumental violence model where men use coercion to capture women's wages. 
Finally, it has been hypothesized that education can increase women's "liberal" beliefs in realms such as gender equality. The evidence here is again mixed. Plausibly exogenous increases in education reduce acceptance of domestic violence in Sierra Leone (Cannonier and Mocan, 2014) and Kenya (Friedman et al., 2011) but has no effect in Turkey (Erten and Keskin, 2015). Gulesci and Meyersson (2013) find that the same Turkish reform studied by Erten and Keskin does lead to lower measured religiosity, such as a lower likelihood of wearing a headscarf. Friedman et al. (2011) further find that education increased political knowledge and reduced acceptance of political authority, but did not lead to corresponding increases in perceived efficacy or participation in community-level political events.

\section{3b. Consequences of increased job availability}

The increased job opportunities for women in developing countries caused by sectoral shifts and trade openness have also had large effects on women's lives. These work opportunities increase the opportunity cost of marriage and childbearing, and indeed, we begin by documenting evidence that job opportunities lead women to delay marriage and fertility. These job opportunities also presumably increase women's outside options, and we accordingly present evidence that women's bargaining power and investments in children indeed increase. We then conclude by pointing out some potential negative consequences of job availability in women's lives, namely, reduced leisure and increased rates of domestic violence.

Jensen (2012) reports the results of an experiment that sent business process outsourcing (BPO) recruiters to rural villages in India. After three years of recruiting services, women in treatment villages between ages 15 and 21 at the baseline were 5 to 6 percentage points less likely to be married or have had their first child. He also documents evidence that knowledge of these job opportunities changed aspirations: women also reported greater desire to continue working after marriage and children.

Heath and Mobarak (2015) show that lower-skilled garment sector jobs in Bangladesh have had similar effects. They examine marriage and fertility rates in villages in Bangladesh after a garment factory opened within commuting distance, estimating that the median exposure to the garment industry in their sample had led to a 28 percent decrease in the probability that an unmarried girl marries and a 29 percent decrease in the probability of first birth. Sivansankaran (2014) demonstrates that textile factories in India had similar effects. She finds that plausibly random increases in employment duration from exposure to a fixed-term contract (versus a daily contract) lead to later marriage and increases in the likelihood that a girl had a say in choosing her husband.

Jobs for women have also led to increased investment in girls' human capital. One potential mechanism is that jobs raise the return to girls and their human capital. Early evidence for this 
hypothesis comes from Rosenzweig and Schultz (1982b), who document that girls' survival rates are higher in Indian districts in which expected female labor supply is greater. Jensen (2012) finds that younger girls (aged 5 to 11) in villages newly aware of business process outsourcing jobs were better nourished and more likely to be enrolled in school. Heath and Mobarak (2015) also find that the opening of garment factories led to increases in girls' education. They argue that garment sector jobs reward basic numeracy and literacy, and point out that the fact that they find education gains among girls whose mother or older sister never worked outside the home indeed suggests that these effects are not due solely to income or time-reallocation effects.

Improved bargaining power is another mechanism linking job opportunities for women to human capital investments in girls, by allowing a woman to direct resources to goods for which she has a stronger preference than other household members. A seminal paper by Duflo (2003) shows that unearned income given to women improves girls' health, and several subsequent papers have shown that the same intuition holds for (potential) earned income. Intrahousehold bargaining models point out that jobs that improve a woman's outside options increase her bargaining power, even if she doesn't take up the job herself. Indeed, Qian (2008) finds that counties in China that grow tea - which women have a comparative advantage in harvesting given the fine motor skills required -- displayed greater survival rates of female children after post-Mao agricultural reforms raised the value of agricultural production. Consistent with an intrahousehold bargaining model in which mothers have a stronger preference for equalizing spending on sons and daughters, she also finds that while increasing potential female income increases education of both genders, increasing potential male income decreases girls' education. Majlesi (2016) also finds that positive shocks to female labor demand - such as those from increased access to export markets -- in Mexico increase women's participation in household decisions and improve children's health.

By comparing workers to non-workers in the same labor market, other papers present evidence that working itself further increases a woman's bargaining power and children's health. Atkin (2009) exploits variation in the number of factory jobs available at the age when women in Mexico can leave school, showing that this availability predicts whether they are working later in life. Women induced to work by jobs available at school-leaving age have children that are one standard deviation taller than other women, and also display greater participation in household decisions. Such improvements could come because earnings potential increases with experience, or because working itself increases a woman's willingness or ability to bargain. Anderson and Eswaran (2009) argue further that working outside the home (versus inside the home or on a husband's farm) can improve a woman's outside option if it requires some irreversible investment, such as building a poultry shed in the rural Bangladeshi context they 
study. They indeed find that women induced to work by rainfall or health shocks are also more likely to participate in household decisions.

Despite evidence of these positive effects, the net effect of job availability on women's welfare remains ambiguous, because relatively less is known about potential negative consequences of labor supply. One concern is reduced leisure time. Thus, while there is evidence that women's labor supply increases men's (Skoufias, 1993; Newman, 2002) and children's (Skoufias, 1997) time in housework, these increases may not compensate for women's entire increased labor supply, especially if there are strong social norms that women do most or all of the housework. Indeed, Skoufias (1993) finds that increased female wages decrease women's leisure time. By contrast, Newman (2002) finds that women in an area of Ecuador where the cut flower industry has expanded do less housework relative to women in an otherwise similar control area, while men do more housework. Since Newman finds that overall female labor supply is not higher in flower areas (but women do work in better-paying jobs), she argues that her findings are driven by women's increased bargaining power.

Another potential negative consequence of job availability for women is intimate partner violence. While standard bargaining models predict that an improved outside option allows a household member to demand better outcomes (such as less violence), certain extensions predict that when violence is used as a tool in bargaining, a better bargaining position for women can indeed lead to more violence. Eswaran and Malhotra (2011) formalize such a model, which predicts that women with low bargaining power face a low risk of violence because the mere threat of violence allows the husband to get his way. But if women gain power, the husband does need to use actual violence to get his way. Heath (2014) finds descriptive evidence in line with this model. The greater prevalence of violence among women who work outside the home in Bangladesh is entirely driven by women with very low education or a young age at marriage, whom she argues are exactly the women whose baseline bargaining power is low, and are thus at increased risk of violence when beginning work in the Eswaran and Malhotra framework.

Causal evidence on this relationship is relatively limited and has mixed findings (in line with the theoretically ambiguous relationship in bargaining models). Potential psychological mechanisms also yield theoretically ambiguous predictions. Psychological backlash - men feel threatened and lash out when their women gain economic independence - could increase violence when women begin working (Gelles, 1972), whereas increased total household income from women's wage can reduce economic stress, which tends to lead to violence (Ellsberg et al., 1999; Martin et al., 1999). Krishnan et al. (2010) examine panel data in Bangalore, India and show that women who begin working between rounds face $80 \%$ higher odds of domestic violence compared to women who did not begin working. Chin (2012) and Luke and Munshi 
(2012) look at temporary changes to women's employment induced by weather shocks in India. While Chin (2012) finds that women induced to work by rainfall shocks that favor female crops face less violence, Luke and Munshi (2011) find that women on tea plantations face greater violence when their income increases, arguing that the resulting shift in resources towards the woman can prompt conflict. Chin proposes "exposure reduction" - the fact that women working spend less time in proximity with their husbands - as a potential mechanism going in the opposite direction and argues that the fact that she finds effects among women with negligible compensation whose husbands don't work in agriculture is evidence for this channel.

\section{Conclusion}

We have documented two trends in developing countries over the past thirty years: rising female education levels and rising female labor force participation. We argue that these trends are interrelated, with gains in female education contributing to the increases in female labor force participation. As a result, even though most countries are on the downward-sloping part of the U-shaped female labor supply curve, the curve has shifted upwards enough that female labor supply has increased even in a majority of low-income countries. As economic conditions continue to change in ways that promote female labor supply - both directly, as countries enact policies to end legal discrimination against female workers or reduce the time cost of home production and childcare, and indirectly, as reductions in trade costs accelerate the shift away from brawn-based activities to light manufacturing or services - a fruitful area of future research will be to document the additional effects of these new policies on female labor supply.

This chapter also discussed the effects of increased education and employment on the lives of women and their children. There is considerable evidence of outcomes that both benefit women and achieve policy-relevant goals. In particular, both education and labor force participation have been shown to delay fertility and lead to healthier children once a woman does have children. However, effects over the life course (such as completed fertility) or that depend on general equilibrium adjustments (such as the timing of marriage or partner choice) are less clearly established and probably context-dependent. A valuable area for future research would be to characterize the factors that determine the heterogeneity in these relationships. Less is also known about potential negative consequences of labor supply on women, such as decreased leisure or increased domestic violence. More research in this area too will ideally help in the design of policies that allow women and society at large to enjoy the benefits of increased job opportunities while minimizing the potential costs. 


\section{References}

Adukia, Anjali. “Sanitation and Education." American Economic Journal: Applied Economics, forthcoming.

Agüero, Jorge M., and Prashant Bharadwaj. "Do the More Educated Know More about Health? Evidence from Schooling and HIV Knowledge in Zimbabwe." Economic Development and Cultural Change 62, no. 3 (2014): 489-517.

AlAzzawi, Shireen. "Trade Liberalization, Industry Concentration and Female Workers: The Case of Egypt." IZA Journal of Labor Policy 3, no. 1 (2014): 1.

Anderson, Siwan, and Mukesh Eswaran. "What Determines Female Autonomy? Evidence from Bangladesh." Journal of Development Economics 90, no. 2 (2009): 179-191.

Andrabi, Tahir, Jishnu Das, and Asim I. Khwaja. “What Did You Do All Day? Maternal Education and Child Outcomes." Journal of Human Resources 47, no. 4 (2012): 873-912.

Angelucci, Manuela, Dean Karlan, and Jonathan Zinman. "Microcredit Impacts: Evidence from a Randomized Microcredit Program Placement Experiment by Compartamos Banco." American Economic Journal: Applied Economics 7, no. 1 (2015): 151-182.

Ashraf, Nava, Erica Field, and Jean Lee. "Household bargaining and excess fertility: an experimental study in Zambia." The American Economic Review 104, no. 7 (2014): 2210-2237.

Atkin, David. "Working for the future: Female factory work and child health in mexico." Unpublished Manuscript, Yale University (2009).

Baird, Sarah, Craig McIntosh, and Berk Ozler. "When the money runs out: do cash transfers have sustained effects on human capital accumulation?." Mimeo, (2016).

Banerjee, Abhijit, Esther Duflo, Rachel Glennerster, and Cynthia Kinnan. “The Miracle of Microfinance? Evidence from a Randomized Evaluation." American Economic Journal: Applied Economics 7, no. 1 (2015): 22-53.

Barrera, Albino. "The Role of Maternal Schooling and Its Interaction with Public Health Programs in Child Health Production." Journal of Development Economics 32, no. 1 (1990): 69-91.

Barros, Ricardo, Pedro Olinto, Trine Lunde, and Mirela Carvalho. "The Impact of Access to Free Childcare on Women's Labor Market Outcomes: Evidence from a Randomized Trial in LowIncome Neighborhoods of Rio de Janeiro." Paper presented at the World Bank Economists' Forum, 2011. 
Beaman, Lori, Esther Duflo, Rohini Pande, and Petia Topalova. "Female Leadership Raises Aspirations and Educational Attainment for Girls: A Policy Experiment in India." Science 335, no. 6068 (2012): 582-586.

Becker, Gary S. The Economics of Discrimination. Chicago: University of Chicago Press, 1957.

Behrman, Jere R., Andrew D. Foster, Mark R. Rosenweig, and Prem Vashishtha. "Women's schooling, home teaching, and economic growth." Journal of political Economy 107, no. 4 (1999): 682-714.

Bhalhotra Sonia, and Damian Clarke "Educational Attainment and Maternal Mortality" Background paper for the UNESCO Education for All Global Monitoring Report 2013/4 (2013).

Black, Sandra E., and Elizabeth Brainerd. "Importing Equality? The Impact of Globalization on Gender Discrimination.” Industrial \& Labor Relations Review 57, no. 4 (2004): 540-559.

Bongaarts, John. “The Causes of Educational Differences in Fertility in Sub-Saharan Africa." Vienna Yearbook of Population Research 2010: 31-50.

Boserup, Ester. “Women's Role in Economic Development.” London: George Allen and Universe, 1970.

Breierova, Lucia, and Esther Duflo. “The Impact of Education on Fertility and Child Mortality: Do Fathers Really Matter Less Than Mothers? (No. w10513)." National Bureau of Economic Research, 2004.

Burde, Dana, and Leigh Linden. “Bringing Education to Afghan Girls: A Randomized Controlled Trial of Village-Based Schools." American Economic Journal: Applied Economics 5, no. 3 (2013): 27-40.

Cannonier, Colin, and Naci Mocan. "Empowering Women Through Education: Evidence from Sierra Leone." Mimeo, (2012).

Chen, Yuyu, and Hongbin Li. "Mother's Education and Child Health: Is There a Nurturing Effect?" Journal of Health Economics 28, no. 2 (2009): 413-426.

Chin, Yoo-Mi. “Male Backlash, Bargaining, or Exposure Reduction? Women's Working Status and Physical Spousal Violence in India." Journal of Population Economics 25, no. 1 (2012): 175-200.

Chou, Shin-Yi, Jin-Tan Liu, Michael Grossman, and Ted Joyce. "Parental Education and Child Health: Evidence from a Natural Experiment in Taiwan." American Economic Journal: Applied Economics 2, no. 1 (2010): 63. 
De Mel, Suresh, David McKenzie, and Christopher Woodruff. "Business Training and Female Enterprise Start-Up, Growth, and Dynamics: Experimental Evidence from Sri Lanka." Journal of Development Economics 106, no. 1 (2014): 199-210.

De Neve, Jan-Walter, Günther Fink, S. V. Subramanian, Sikhulile Moyo, and Jacob Bor. "Length of secondary schooling and risk of HIV infection in Botswana: evidence from a natural experiment." The Lancet Global Health 3, no. 8 (2015): e470-e477.

De Walque, Damien. "Parental Education and Children's Schooling Outcomes: Evidence from Recomposed Families in Rwanda." Economic Development and Cultural Change 57, no. 4 (2009): 723-746.

Deininger, Klaus, Aparajita Goyal, and Hari Nagarajan. “Women's Inheritance Rights and Intergenerational Transmission of Resources in India." Journal of Human Resources 48, no. 1 (2013): 114-141.

Desai, Sonalde, and Soumya Alva. "Maternal Education and Child Health: Is There a Strong Causal Relationship?" Demography 35, no. 1 (1998): 71-81.

Doepke, Matthias, and Fabian Kindermann. "Bargaining over Babies: Theory, Evidence, and Policy Implications." (No. w22072). National Bureau of Economic Research, 2016.

Duflo, Esther. "Grandmothers and granddaughters: old-age pensions and intrahousehold allocation in South Africa." The World Bank Economic Review 17, no. 1 (2003): 1-25.

Duflo, Esther, Pascaline Dupas, and Michael Kremer. “Education, HIV, and Early Fertility: Experimental Evidence from Kenya." American Economic Review 105, no. 9 (2015): 2757-2797.

Ellsberg, Mary C., Rodolfo Pena, Andres Herrera, Jerker Liljestrand, and Anna Winkvist. "Wife Abuse among Women of Childbearing Age in Nicaragua." American Journal of Public Health 89, no. 2 (1999): 241-244.

Erten, Bilge, and Pinar Keskin. "For Better or for Worse?: Education and the Prevalence of Domestic Violence in Turkey." American Economic Journal: Applied Economics, (Forthcoming).

Eswaran, Mukesh, and Nisha Malhotra. "Domestic Violence and Women's Autonomy in Developing Countries: Theory and Evidence." Canadian Journal of Economics/Revue canadienne d'économique 44, no. 4 (2011): 1222-1263.

Field, Erica, and Attila Ambrus. “Early Marriage, Age of Menarche, and Female Schooling Attainment in Bangladesh." Journal of Political Economy 116, no. 5 (2008): 881-930. 
Field, Erica, Seema Jayachandran, and Rohini Pande. "Do Traditional Institutions Constrain Female Entrepreneurship? A Field Experiment on Business Training in India." American Economic Review Papers and Proceedings 100, no. 2 (2010): 125-129.

Field, Erica, Seema Jayachandran, Rohini Pande, and Natalia Rigol. “Friendship at Work: Can Peer Effects Catalyze Female Entrepreneurship?" American Economic Journal: Economic Policy 8, no. 2 (2016): 125-153.

Friedman, Willa, Michael Kremer, Edward Miguel, and Rebecca Thornton. “Education as Liberation?" (No. w16939). National Bureau of Economic Research, 2011.

Gaddis, Isis, and Janneke Pieters. "The Gendered Labor Market Impacts of Trade Liberalization: Evidence from Brazil." Journal of Human Resources (2016).

Gelles, Richard J. “The Violent Home: A Study of Physical Aggression between Husbands and Wives." Beverly Hills: Sage Publications. 1972.

Glewwe, Paul. “Why Does Mother's Schooling Raise Child Health in Developing Countries? Evidence from Morocco." Journal of Human Resources 34, no.1, (1999): 124-159.

Goldin, Claudia. "The U-Shaped Female Labor Force Function in Economic Development and Economic History." In Women's Human Capital and Economic Development, edited by T. P. Schultz.Chicago University of Chicago Press, 1995: 61-90.

Gonzales, Christian, Sonali Jain-Chandra, Kalpana Kochhar, and Monique Newiak. "Fair Play: More Equal Laws Boost Female Labor Force Participation.” IMF Staff Discussion Note, December 2015.

Grépin, Karen A., and Prashant Bharadwaj. "Maternal Education and Child Mortality in Zimbabwe." Journal of Health Economics 44 (2015): 97-117.

Gulesci, Selim, and Erik Meyersson. "For the Love of the Republic: Education, Religion, and Empowerment." Working Paper, 2013.

Güneş, Pınar M. “The Role of Maternal Education in Child Health: Evidence from a Compulsory Schooling Law." Economics of Education Review 47 (2015): 1-16.

Heath, Rachel. "Women's access to labor market opportunities, control of household resources, and domestic violence: Evidence from Bangladesh." World Development 57 (2014): 32-46.

Heath, Rachel, and Ahmed Mushfiq Mobarak. "Manufacturing Growth and the Lives of Bangladeshi Women." Journal of Development Economics 115 (2015): 1-15. 
Jayachandran, Seema. “The Roots of Gender Inequality in Developing Countries.” Annual Review of Economics 7 (2015): 63-88.

Jayachandran, Seema, and Adriana Lleras-Muney. "Life Expectancy and Human Capital Investments: Evidence from Maternal Mortality Declines." Quarterly Journal of Economics 124, no. 1 (2009): 349-397.

Jensen, Robert. “Do Labor Market Opportunities Affect Young Women's Work and Family Decisions? Experimental Evidence from India." Quarterly Journal of Economics, 127 (no.2) (2012): 753-792.

Keats, Anthony. Women's schooling, fertility, and child health outcomes: Evidence from Uganda's free primary education program. Mimeo (2014).

Klasen, Stephan, and Janneke Pieters. “What Explains the Stagnation of Female Labor Force Participation in Urban India?" World Bank Economic Review 29, no. 3 (2015): 449-478.

Krishnan, Suneeta, Corinne H. Rocca, Alan E. Hubbard, Kalyani Subbiah, Jeffrey Edmeades, and Nancy S. Padian. "Do Changes in Spousal Employment Status Lead to Domestic Violence? Insights from a Prospective Study in Bangalore, India." Social Science and Medicine 70, no. 1 (2010): 136-143.

Lavy, Victor, and Alexander Zablotsky. "Mother's Schooling, Fertility, and Children's Education: Evidence from a Natural Experiment." NBER Working Paper No. 16856. National Bureau of Economic Research, 2011.

Luke, Nancy, and Kaivan Munshi. "Women as Agents of Change: Female Income and Mobility in India." Journal of Development Economics 94, no. 1 (2011): 1-17.

Majlesi, Kaveh. “Labor Market Opportunities and Women's Decision Making Power within Households." Journal of Development Economics 119 (2016): 34-47.

Mammen, Kristin, and Christina Paxson. "Women's Work and Economic Development." Journal of Economic Perspectives 14, no. 4 (2000): 141-164.

Martin, Sandra L., Amy O. Tsui, Kuhu Maitra, and Ruth Marinshaw. “Domestic Violence in Northern India." American Journal of Epidemiology 150, no. 4 (1999): 417-426.

Martin, Teresa C. “Women's Education and Fertility: Results from 26 Demographic and Health Surveys." Studies in Family Planning, 26, (no. 4) 1995: 187-202.

Menon, Nidhiya, and Yana Van der Meulen Rodgers. "International Trade and the Gender Wage Gap: New Evidence from India's Manufacturing Sector.” World Development 37, no. 5 (2009): 965-981. 
Miller, Grant. “Contraception as Development? New Evidence from Family Planning in Colombia." Economic Journal 120, no. 545 (2010): 709-736.

Muralidharan, Karthik, and Nishith Prakash. "Cycling to School: Increasing Secondary School Enrollment for Girls in India." Working Paper 19305. National Bureau of Economic Research, 2013.

Newman, Constance. "Gender, Time Use, and Change: The Impact of the Cut Flower Industry in Ecuador." World Bank Economic Review 16, no. 3 (2002): 375-395.।

Osili, Una Okonkwo, and Bridget Terry Long. "Does female schooling reduce fertility? Evidence from Nigeria." Journal of Development Economics 87, no. 1 (2008): 57-75.

Ozier, Owen. "The impact of secondary schooling in Kenya: A regression discontinuity analysis." Journal of Human Resources (2016).

Pitt, Mark M., Mark R. Rosenzweig, and Mohammad N. Hassan. "Human Capital Investment and the Gender Division of Labor in a Brawn-Based Economy." American Economic Review 102, no. 7 (2012): 3531-3560.

Psacharopoulos, George, and Zafiris Tzannatos. "Female labor force participation: An international perspective." The World Bank Research Observer 4, no. 2 (1989): 187-201.

Qian, Nancy. "Missing women and the price of tea in China: The effect of sex-specific earnings on sex imbalance." The Quarterly Journal of Economics 123, no. 3 (2008): 1251-1285.

Rasul, Imran. "Household Bargaining over Fertility: Theory and Evidence from Malaysia." Journal of Development Economics 86, no. 2 (2008): 215-241.

Rosenzweig, Mark R., and T. Paul Schultz. "Child Mortality and Fertility in Colombia: Individual and Community Effects." Health Policy and Education 2, no. 3 (1982a): 305-348.

Rosenzweig, Mark R., and T. Paul Schultz. "Market Opportunities, Genetic Endowments, and Intrafamily Resource Distribution: Child Survival in Rural India." American Economic Review 72, no. 4 (1982b): 803-815.

Rosenzweig, M. R., and T. Paul Schultz. "Schooling, Information and Nonmarket Productivity: Contraceptive Use and Its Effectiveness." International Economic Review 30, no. 2 (1989): 457-477.

Roy, Sanchari. "Empowering Women: Inheritance Rights and Female Education in India." Mimeo, Warwick University, 2013. 
Schultz, T. Paul. "Interpretation of Relations among Mortality, Economics of the Household, and the Health Environment." In Socioeconomic Determinants and Consequences of Mortality Differentials. Geneva: WHO, 1980.

Schultz, T. Paul. "School Subsidies for the Poor: Evaluating the Mexican Progresa Poverty Program." Journal of Development Economics 74, no. 1 (2004): 199-250.

Sivasankaran, Anitha. "Essays on gender, intra-household allocation and development." PhD dissertation, 2014.

Skoufias, Emmanuel. "Labor market opportunities and intrafamily time allocation in rural households in South Asia." Journal of Development Economics 40, no. 2 (1993): 277-310.

Thomas, Duncan. "Intra-Household Resource Allocation: An Inferential Approach.” Journal of Human Resources 25, (no. 4) (1990): 635-664.

Thomas, Duncan, John Strauss, and Maria-Helena Henriques. "Child Survival, Height for Age and Household Characteristics in Brazil." Journal of Development Economics 33, no. 2 (1990): 197234.

Tsai, Wehn-Jyuan, Jin-Tan Liu, Shin-Yi Chou, and Michael Grossman. "Intergeneration Transfer of Human Capital: Results from a Natural Experiment in Taiwan." (No. 16876). National Bureau of Economic Research, 2011.

Valdivia, Martin. "Business Training Plus for Female Entrepreneurship? Short and MediumTerm Experimental Evidence from Peru." Journal of Development Economics 113 (2015): 33-51.

Wolfe, Barbara L., and Jere R. Behrman. "Determinants of Child Mortality, Health, and Nutrition in a Developing Country." Journal of Development Economics 11, no. 2 (1982): 163-193.

Wolfe, Barbara L., and Jere R. Behrman. "Women's Schooling and Children's Health: Are the Effects Robust with Adult Sibling Control for the Women's Childhood Background?" Journal of Health Economics 6, no. 3 (1987): 239-254.

World Bank. World Development Report 2012: Gender Equality and Development. Washington, DC: World Bank, 2012. 
Figure 1

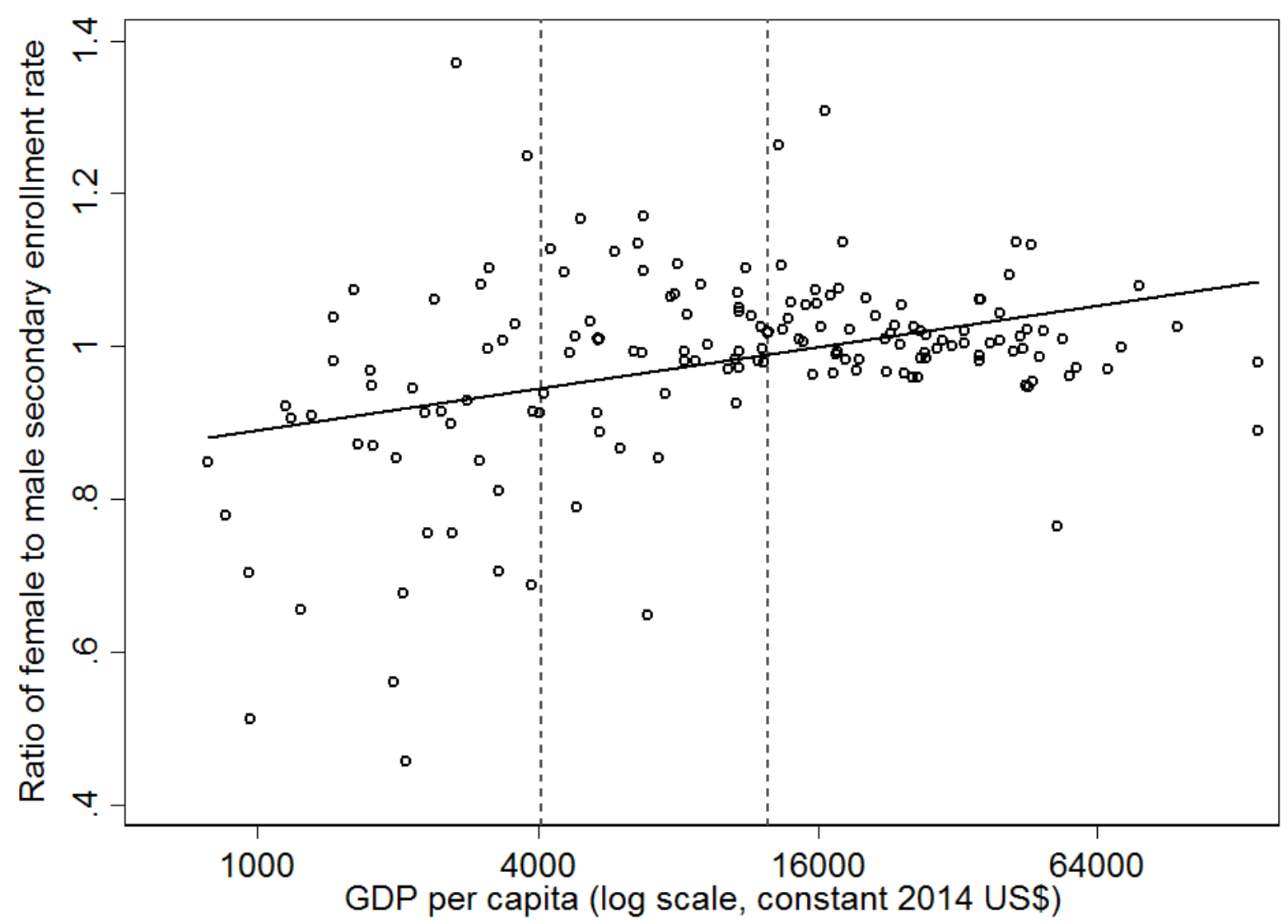

Notes: GDP per capita is the purchasing power parity-adjusted value in the year in which secondary school enrollment data is measured (the latest available); school enrollment data are from the World Bank's World Development Indicators. The vertical lines represent the thresholds between lower and lower-middle-income countries (\$4000 in 2014 dollars), and between lower-middle or upper-middle-income countries (about \$12,500). Two possible definitions of "developing countries" are countries below these thresholds. 
Figure 2

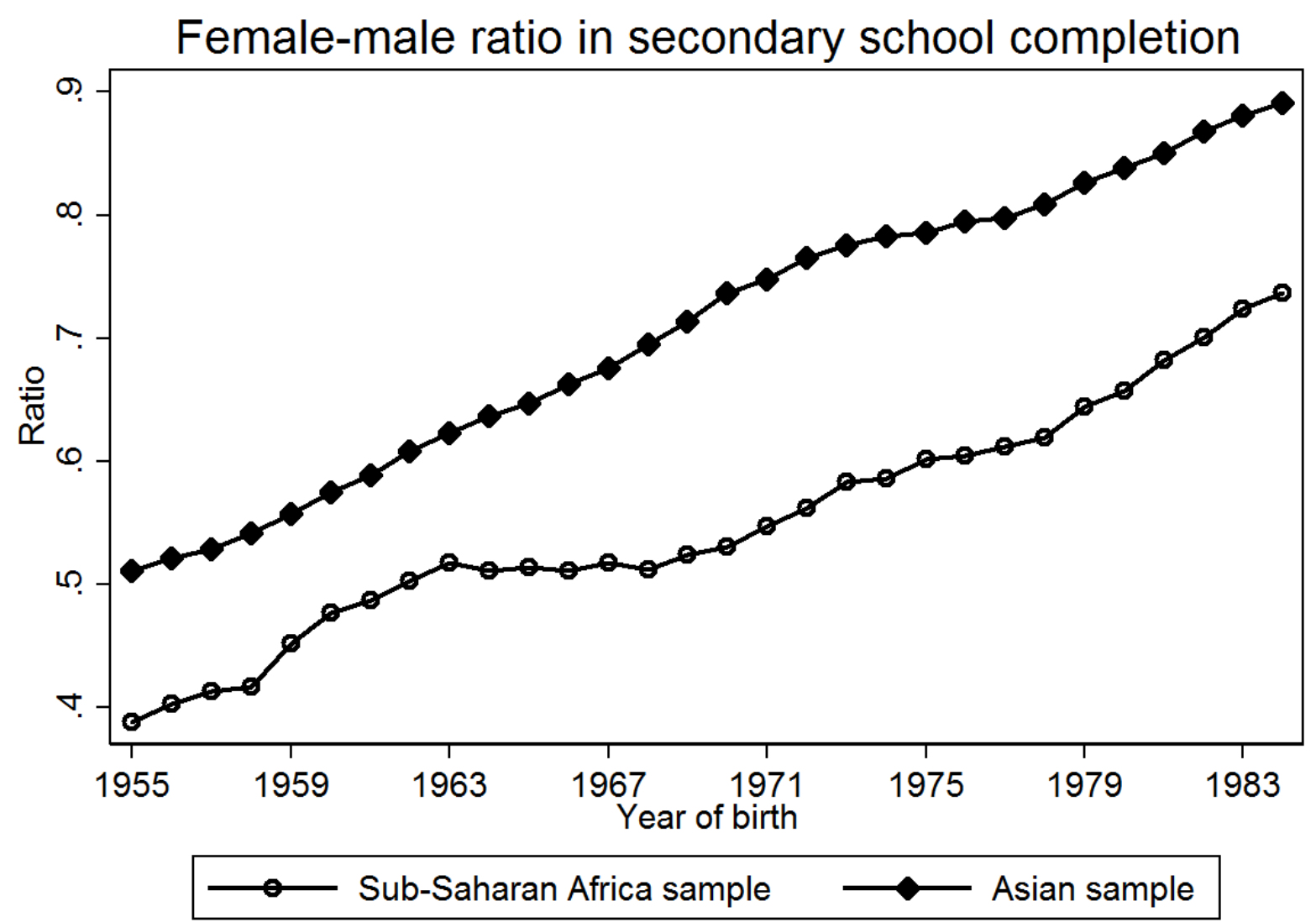

Notes: Data are from the International Public Use Microdata (IPUMS) database. Countries included are those classified by the World Bank as low-income or lower-middle-income, with an IPUMS sample available for 2005 or later. In cases of multiple IPUMS samples meeting the criterion, the most recent one is used. In aggregating to regions, samples are re-weighted such that each observed individual within a region is weighted equally. 
Figure 3

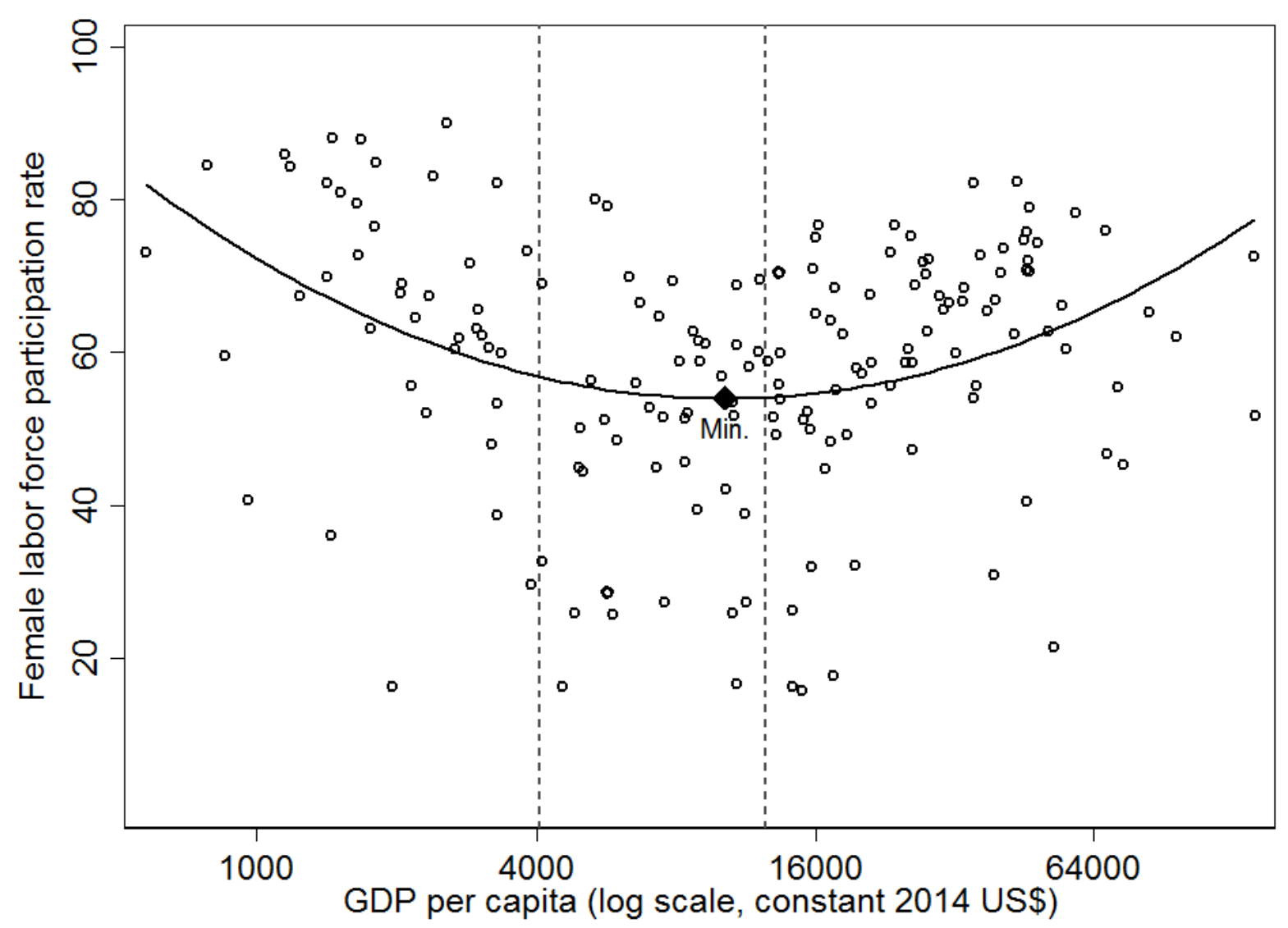

Notes: GDP per capita is the purchasing power parity-adjusted value in 2014; female labor force participation is for females age 15-64 and is from the World Bank's World Development Indicators. The vertical lines represent the thresholds between lower and lower-middle-income countries (\$4000 in 2014 dollars), and between lower-middle or upper-middle-income countries (about $\$ 12,500)$. 
Figure 4

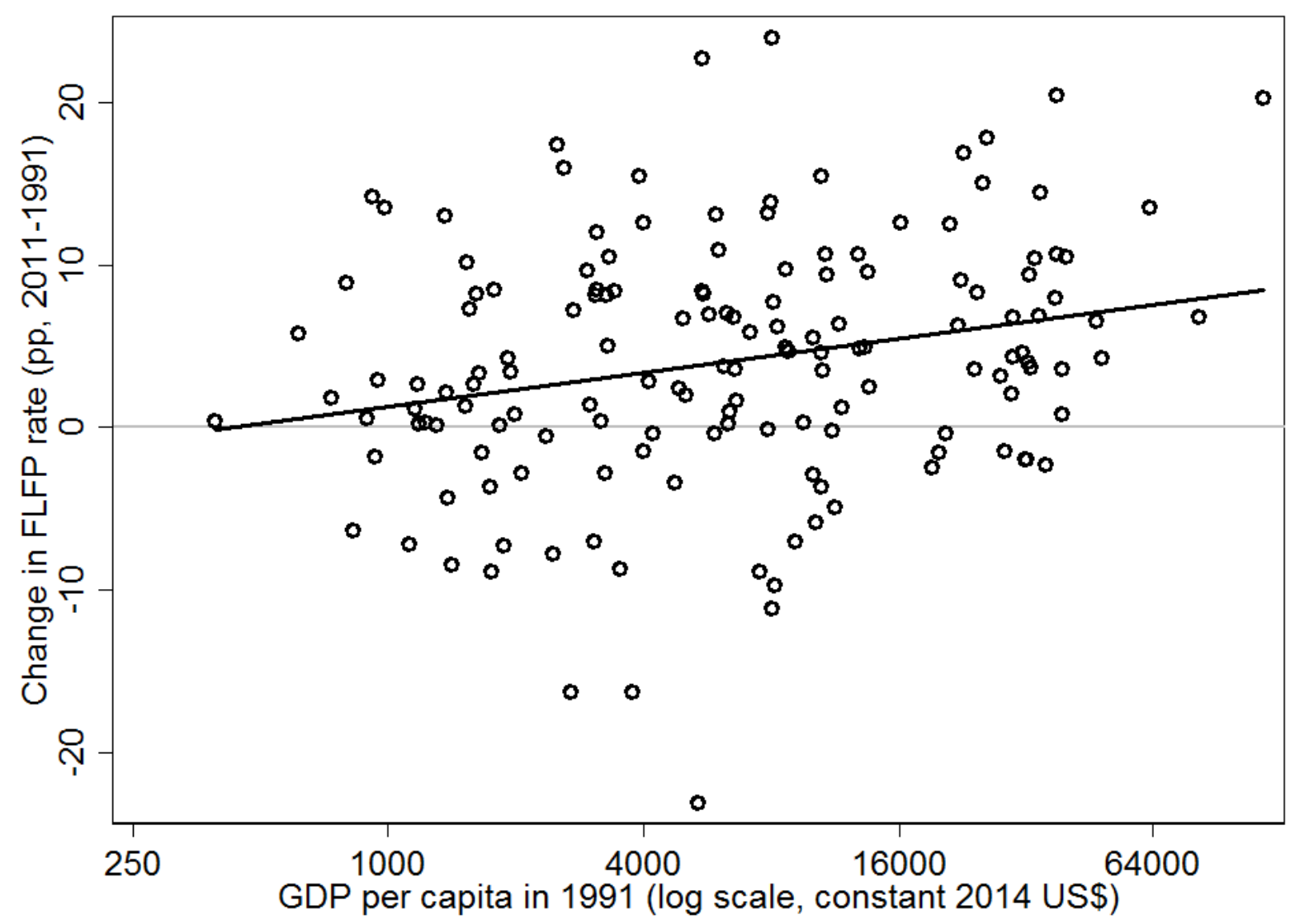

Notes: GDP per capita is the purchasing power parity-adjusted value. Female labor force participation (FLFP) data are from the World Bank's World Development Indicators. Data for all years are three-year averages centered on the indicated year. 
Figure 5

Panel A: Each country weighted equally

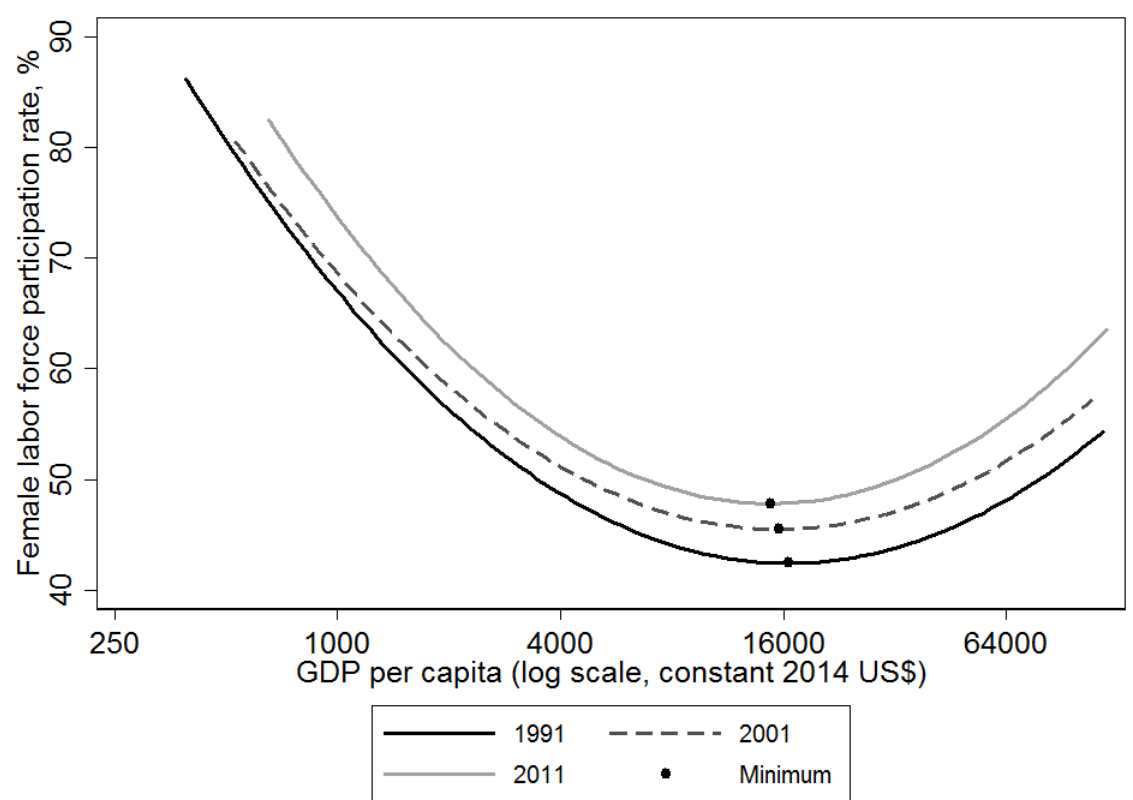

Panel B: Weighted by population size

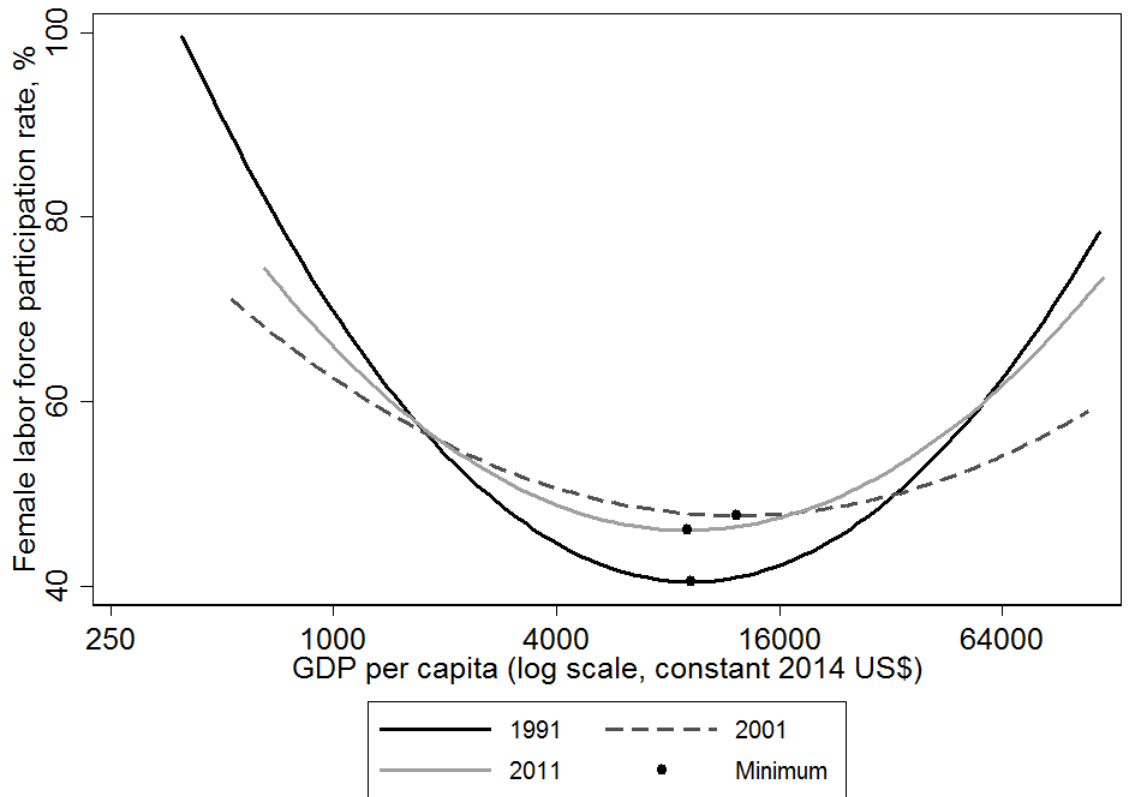

Notes: GDP per capita is the purchasing power parity-adjusted value. Female labor force participation data are from the World Bank's World Development Indicators. Data for all years are three-year averages centered on the indicated year. 